\title{
IMPROVING THE PERFORMANCE OF MICRO SPRINKLERS IRRIGATION BY REDUCING ITS RANDOM MOTION
}

\author{
Adel M. Elmetwalli and M. A. Bek
}

ABSTRACT

Limited fresh water resources become a serious issue worldwide particularly arid and semi-arid conditions. Therefore more efficient irrigation systems are fundamentally required to increase water productivity. Micro sprinklers are among these new systems to maximize irrigation efficiency. Random motion of micro sprinklers head reduces the uniformity of water. This study aimed to improve water distribution efficiency of micro sprinklers by reducing its random motion. The study investigated the effects of operating pressure, sprinkler height on the performance of micro sprinklers before and after modification. Irrigation system was operated at four different levels of operating pressure (150, 180, 220 and $250 \mathrm{kPa}$ ) and three different sprinkler heights of 0.5, 1.0 and $1.5 \mathrm{~m}$. Water distribution efficiency was evaluated through the calculation of Christiansen's uniformity coefficient (CCU) and distribution uniformity (DU). The highest CCU and DU values of $91.8 \%$ and $86 \%$ were recorded with $250 \mathrm{kPa}$ operating pressure, and $1.5 \mathrm{~m}$ sprinkler height when using copper support followed by same conditions when using PVC tubes. Therefore, sprinklers without support produced less water distribution efficiency in comparison to cases of copper and $P V C$ tubes. The results thus revealed that water distribution efficiency can be maximized through reducing random motion of sprinkler head and choosing the optimum operating conditions (e.g. operating pressure and sprinkler height).

Keywords: micro-sprinklers, operating pressure, height, distribution uniformity, random motion

\section{INTRODUCTION}

Trigation technique is among the most important factors influencing agricultural production worldwide. However, it is among major activities which consume the biggest amount of water resources (Rijsberman, 2006).

*Assi. Prof., Agric. Eng. Dept., Fac. of Agric., Tanta Univ.

**Assi. Prof. Phys. and Eng. Math. Dept., Fac. of Eng, Tanta Univ. 
Water scarcity is the most limiting factor for agricultural crop production particularly in arid and-semi arid environments. Therefore more efficient water management is crucially needed to sustain rapid population growth worldwide. The selection of proper irrigation method should be such that, maximum efficiencies including distribution uniformity, application efficiency and storage efficiency are attained (Shendage and Gadge, 2011). Water is a natural resource of crucial importance and thus practices that provide efficient use of water are extremely significant (Armindo et al., 2011). Managing irrigation systems to maximize the net return for producers in case of water scarcity is a critical important challenge to agricultural scientists, irrigation engineers and producers (English et al., 1982).

Micro-sprinkler irrigation method is an efficient way to apply water to crops grown in open fields and even inside green houses. This way is favoured over traditional sprinkler irrigation methods and drip irrigation for growing vegetables and orchard crops (Shendage and Gadge, 2011). They threw water into air in a specific pattern. Micro sprinklers are advantageous over drip irrigation because fewer sprinklers are needed to water larger area. They are emitters mainly known as sprinklers or spray heads where there are many types of micro-sprinklers based on throwing water into air. According to the way of throwing water into air, microsprinklers are classified into mini-sprays, jets, spinners and micro sprays (Aung and Thomas, 2003). Micro sprinklers have some advantages over other irrigation systems including improved water and nutrients management, feasibility for higher yield and greater control of applied water. When properly managed, micro irrigation can provide soil water, minimize leaching of soluble salts and crop water requirements. These main advantages obviously demonstrate the importance of micro irrigation to improve water productivity and economic returns.

Water distribution uniformity is considered one of the most important efficiency indicators in sprinkler irrigation systems assessment. It directly affects the productivity of different crops (Li and Rao, 2000; Dechmi et al., 2003). Long-tube micro sprinklers are commonly used for the irrigation of fruit trees and crops grown inside green houses. The main 
problem of long-tube micro sprinklers is low water distribution efficiency as a result of sprinkler head random motion that occurs at high pressures. Increasing water velocity inside the tube increases friction losses and can increase alongside movement and thus random motion. The colliding between water and the nozzle bed also increases sprinkler random motion. The overall aim of this research was to investigate the potential of improving the performance of micro sprinklers through decreasing sprinklers head random motion and to evaluate its performance under different operating pressures and sprinkler heights.

\section{MATERIALS AND METHODS}

The experimental work of this study was undertaken in a private farm for growing ornamental plants and fruit transplants, Minofia province, Egypt in 2015 winter season. A $6 \mathrm{hp}$ pump was used to supply water to irrigation network. Fig. 1 shows sprinkler head and connecting base to the main line (2.54 cm diameter). Micro-sprinklers (EIN DOR) were mounted at specific heights $(0.5,1$ and $1.5 \mathrm{~m})$ and were tested at different operating pressures $(150,180,220$, and $250 \mathrm{kPa}) .10 \mathrm{~cm}$ diameter and 5 $\mathrm{cm}$ height plastic catch cans were used to collect water under sprinklers and were distributed according to ASAE standard, 2001. Sprinkler discharge rate was determined by using a flexible hose which can be connected directly to the sprinkler nozzle.

\section{Discharge rate}

A 3 litre container was used to collect water for a certain time and the discharge rate was calculated according to Melvyn, 1983 as follows:

$$
\mathrm{Q}=\mathrm{v} / \mathrm{t}
$$

Where; $\mathrm{Q}$ is the discharge rate in $1 / \mathrm{min}$; $\mathrm{T}$ is the time in min and $\mathrm{V}$ is the volume of collected water

To improve water distribution efficiency of micro sprinklers, two different support pipes (copper and PVC) were installed on the flexible tube of the micro sprinkle. A $20 \mathrm{~cm}$ length copper pipe weighing $81.9 \mathrm{~g}$ and a $20 \mathrm{~cm}$ length PVC pipe weighing $26.1 \mathrm{~g}$ were used for this purpose. The performance of long tube micro sprinklers before and after modification was evaluated at different operating pressure and different 
sprinkler heights. A valve was used to control the operating pressure and a manometer (pressure gage) was used to adjust the pressure at a certain value. Irrigation network was operated for ten minutes before collecting water samples to ensure that pipelines are completely full of water.

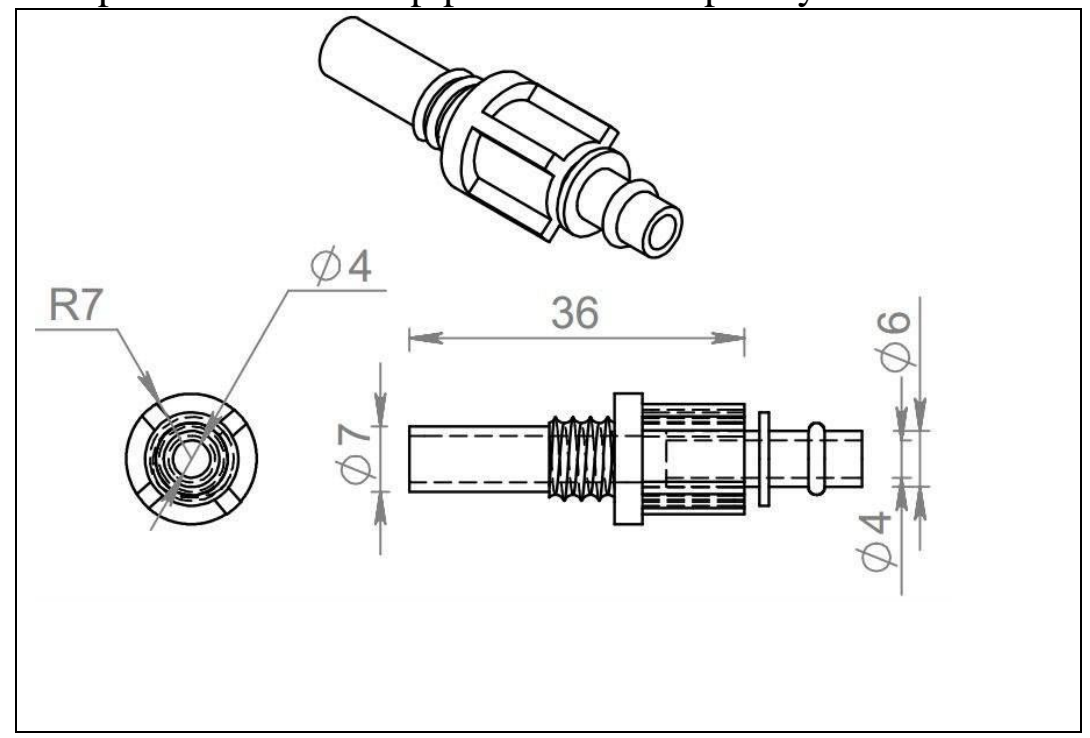

Connecting base to main line

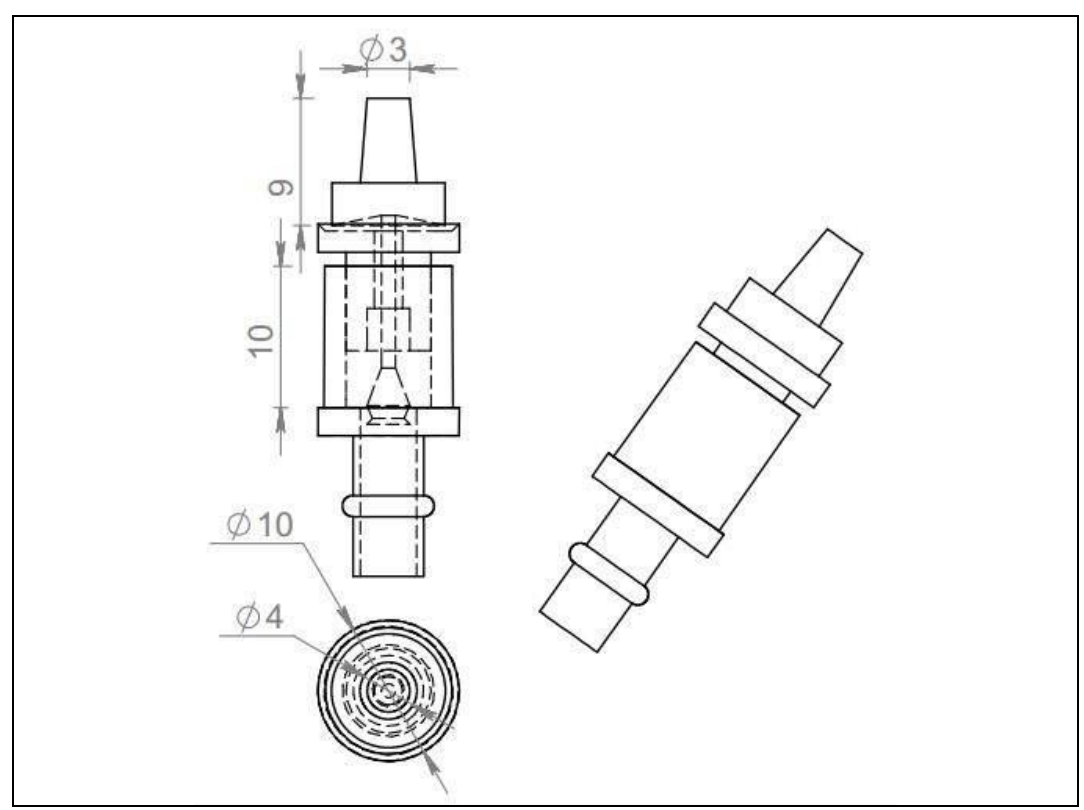

Sprinkler head

Fig. 1 Both sprinkler head and connecting base to the main line 


\section{Velocity contour maps}

Velocity contour maps were created using ANSYS FLUENT 14 software package. Data of discharge rate, diameters of both main line, and flexible tube inner diameter and sprinkler nozzle diameter were taken into account to create these maps. (Anderson, 1995) put the Computational Fluid Dynamics (CFD) as a new third approach in the philosophical study and development of the whole discipline of fluid dynamics. So that in order to have insight investigations to water flow inside the piping system or even in the very relatively narrow sprinkler tube, ANSYS FLUENT was employed. This technique allows us to investigate water velocity profiles and distribution. Based on the application of basic fluid governing equations (Navier-Stokes equations, which are based on the assumptions of conservation of mass and momentum in a moving fluid. The conservation of mass is described by the following partial differential equation

$$
\frac{\partial \rho}{\partial t}+\nabla \cdot(\rho \vec{V})=0
$$

Where $\rho\left(\mathrm{kg} \mathrm{m}^{-3}\right)$ is the density and $V$ is the velocity vector of the fluid.

Momentum equation was also considered

$$
\rho \frac{\partial \vec{V}}{\partial t}+\rho(\vec{V} \cdot \nabla) \vec{V}=-\nabla p+\rho \vec{g}+\nabla \cdot \tau_{i j}+\mathrm{F}
$$

Where $\mathrm{p}$ is the pressure in $\mathrm{Pa}$ and $\tau$ is the stress tensor, $\mathrm{F}$ is the external body force in $\mathrm{N} / \mathrm{m}^{3}$. The meshing was created by considering key flow physics and the required level of accuracy to represent the piping system geometry.

\section{Distribution uniformity (DU)}

Distribution uniformity is one of the most commonly used indicators for evaluating sprinkler irrigation and it is calculated according to Heerman et al., 1990.

$$
\mathrm{DU}=100\left(\mathrm{Z}_{\mathrm{lq}} / \mathrm{Z}_{\mathrm{av}}\right)
$$

Where DU is the distribution uniformity in \% $\mathrm{Z}_{\mathrm{lq}}$ is the mean depth in catch cans of the low quarter in $\mathrm{mm}$ $Z_{a v}$ is the mean depth in all catch cans in $\mathrm{mm}$

\section{Christiansen's coefficient of uniformity (CCU)}


The amounts of water caught in catch cans were also used to calculate the Christiansen's coefficient of uniformity as follows:

$$
\mathrm{CCU}=100\left[1-\frac{\Sigma\left|x_{i}-x^{\prime}\right|}{n x^{\prime}}\right]
$$

Where, CCU is the Christiansen's coefficient of uniformity, \%

$\mathrm{X}_{\mathrm{i}}$ is the amount caught at a specific point, $\mathrm{mm}$

$\mathrm{x}^{\prime}$ is the mean of all amounts caught in catch cans, $\mathrm{mm}$

$\mathrm{n}$ is the number of catch cans used

\section{RESULTS AND DISCUSSION}

\section{Association between operating pressure and discharge rate}

At various operating pressure, discharge rate was identified as a mean of five replicates. The data of recorded discharge rate are illustrated in Fig. 2. as seen in the figure at all levels of operating pressure, discharge rate increased with increasing operating pressure. The scattering plot for the data of discharge rate and pressure values was created to depict the relationship between them producing the following equation:

$\mathrm{q}=0.04 \mathrm{P}^{0.74} \quad \mathrm{R}^{2}=0.92$

As seen in Fig. 2 there is a positive relationship between operating pressure and discharge rate. The highest discharge rate of $2.441 / \mathrm{min}$ was recorded with $250 \mathrm{kPa}$ while the minimum discharge rate of $1.53 \mathrm{1} / \mathrm{min}$ was recorded with $150 \mathrm{kPa}$

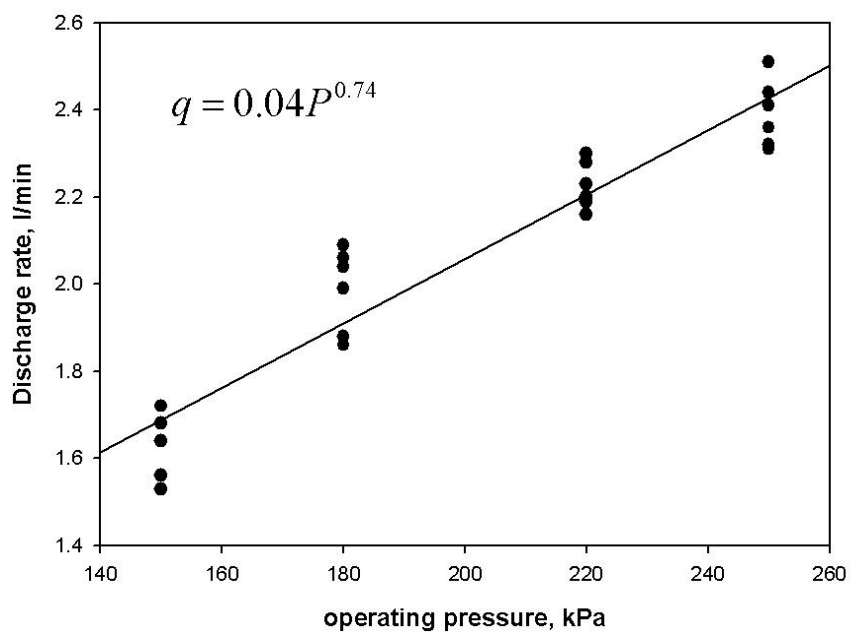

Fig. 2 Mean discharge rate as affected by operating pressure 


\section{Association between water velocity and random motion of sprinkler head}

It is well known that friction losses increase with increasing water velocity in pipelines. Increasing water velocity as a result of increasing water discharge rate causes the random motion of sprinkler head. Fig. 3 illustrates velocity contours profile which clearly shows that water velocity at the exit of sprinkler nozzle recorded the maximum value at $250 \mathrm{kPa}$ operating pressure while the minimum value was recorded at 150 $\mathrm{kPa}$ operating pressure. The friction between water and the inner pipeline's wall generates alongside pressure that increases gradually from the main line reaching a maximum at the water exit and resultantly increases the random motion of the sprinkler head. This random motion leads to low water distribution efficiency. To decrease this random motion, the movement of the sprinkler head should be decreased. In this context, copper and PVC tubes can serve as a support to decrease this random motion. Both tubes can reduce it by eliminating high portion of the alongside pressure force.

Fig. 3 shows the velocity distribution inside the sprinkler tube. The figure shows a gradient in velocity magnitude in different colours. The legend shows that high velocity is expressed in red colour, medium velocity in light green colour and lower velocity in blue colours. The results indicated that the velocity at the centre is the highest where it tends to be there at the inner surface of the tube. This refers to the friction between the inner surface of the tube and water. Therefore, increasing water velocity at the exit of the sprinkler nozzle increases kinetic energy of water particles and thus increases colliding between water and the lower part of the sprinkler head that breaks up water into small droplets. The figure represents the velocity distribution along straight line just before the inlet of the tube. It is clear that the velocity is at its maximum magnitude at the middle of the tube while it is less near the tube's wall. 


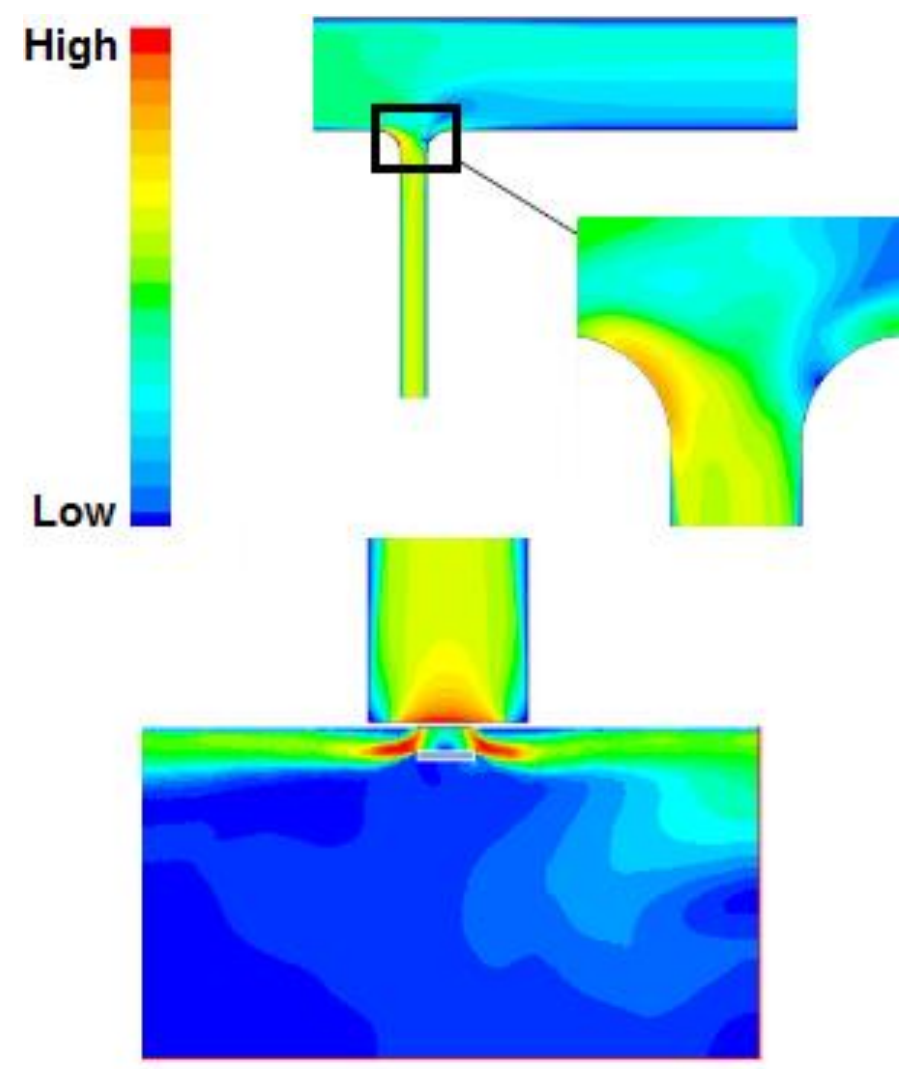

Fig. 3 Velocity contour distribution throughout the piping system showing areas of high and low velocity.

CFD was used to describe and produce mesh in the whole piping system as an indicator of water velocity in the piping system. The details of the mesh are shown in Fig. 4-a. The mesh elements designed so that it is smaller in the areas where there is a change in water direction as shown in the figure. In addition, the size of the mesh elements were designed to be smaller in the outlet of the sprinkler tube as it is theoretically expected to have the maximum velocity as illustrated in the figure. This reduction of cells at these particular areas ensures the capturing of all details and enhances the numerical simulation. In the presented simulation model the two-equation $k$ - $\varepsilon$ turbulence model was adopted (Malalalsekera., 2007). The presented approach of using CFD was implemented successfully in (Wei et al., 2006). They simulated the flow in labyrinth 
channels to calculate the distributions of pressure and velocity of the flow, and in addition, the authors calculated the relationship between pressure and rate of discharge for channels with three different shapes: triangular, rectangular, and trapezoidal. They concluded that triangular channel had the highest efficiency of hydraulic energy dissipation.

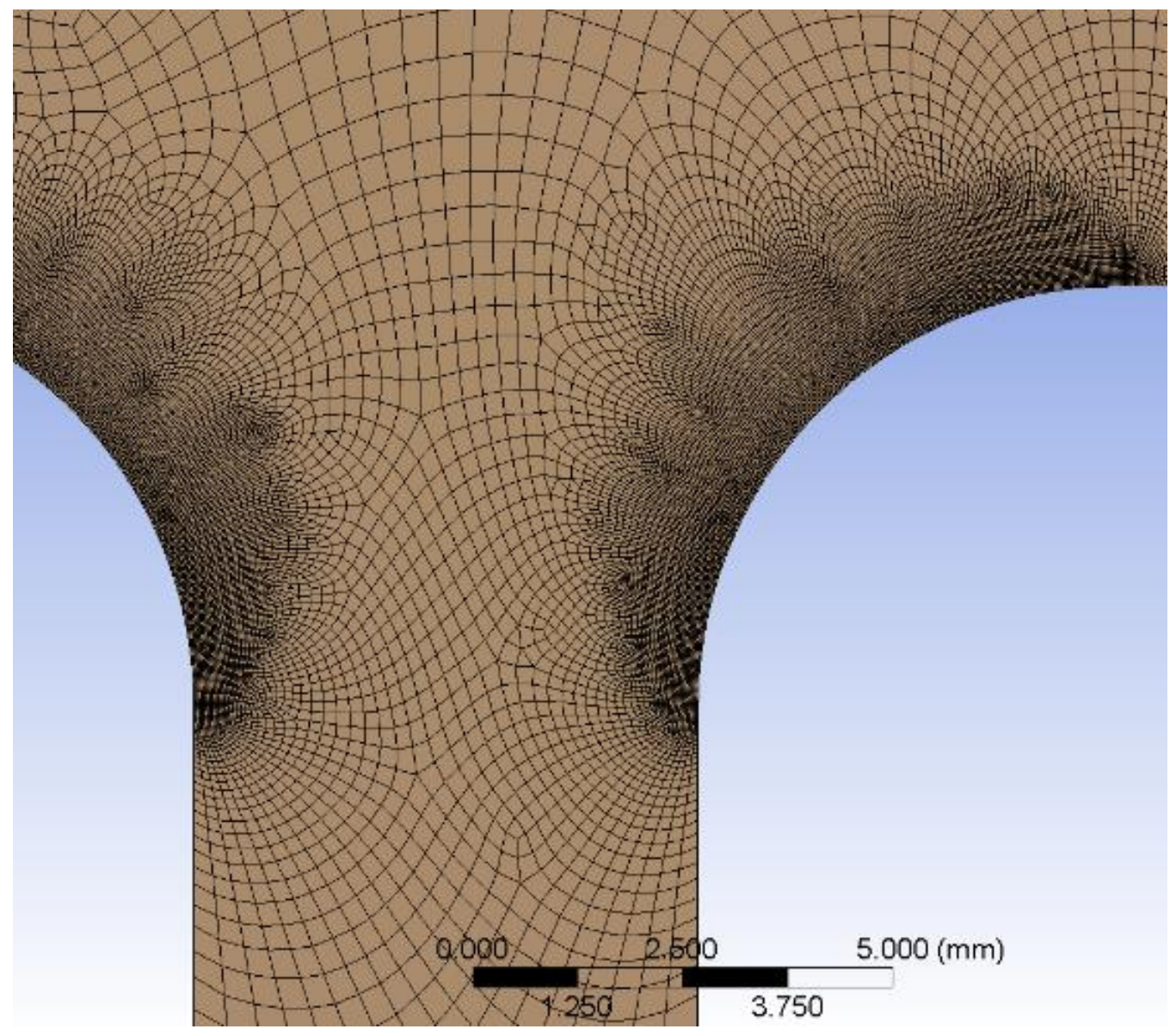

Figure 4-a

Certain areas with high physical change of water movement were chosen to show the mesh as an indicator of water velocity. These areas with high change in water velocity are; at the connection between sprinkler tube and mainline, middle of the tube and at water exit from the sprinkler nozzle (Fig. 4-b). 


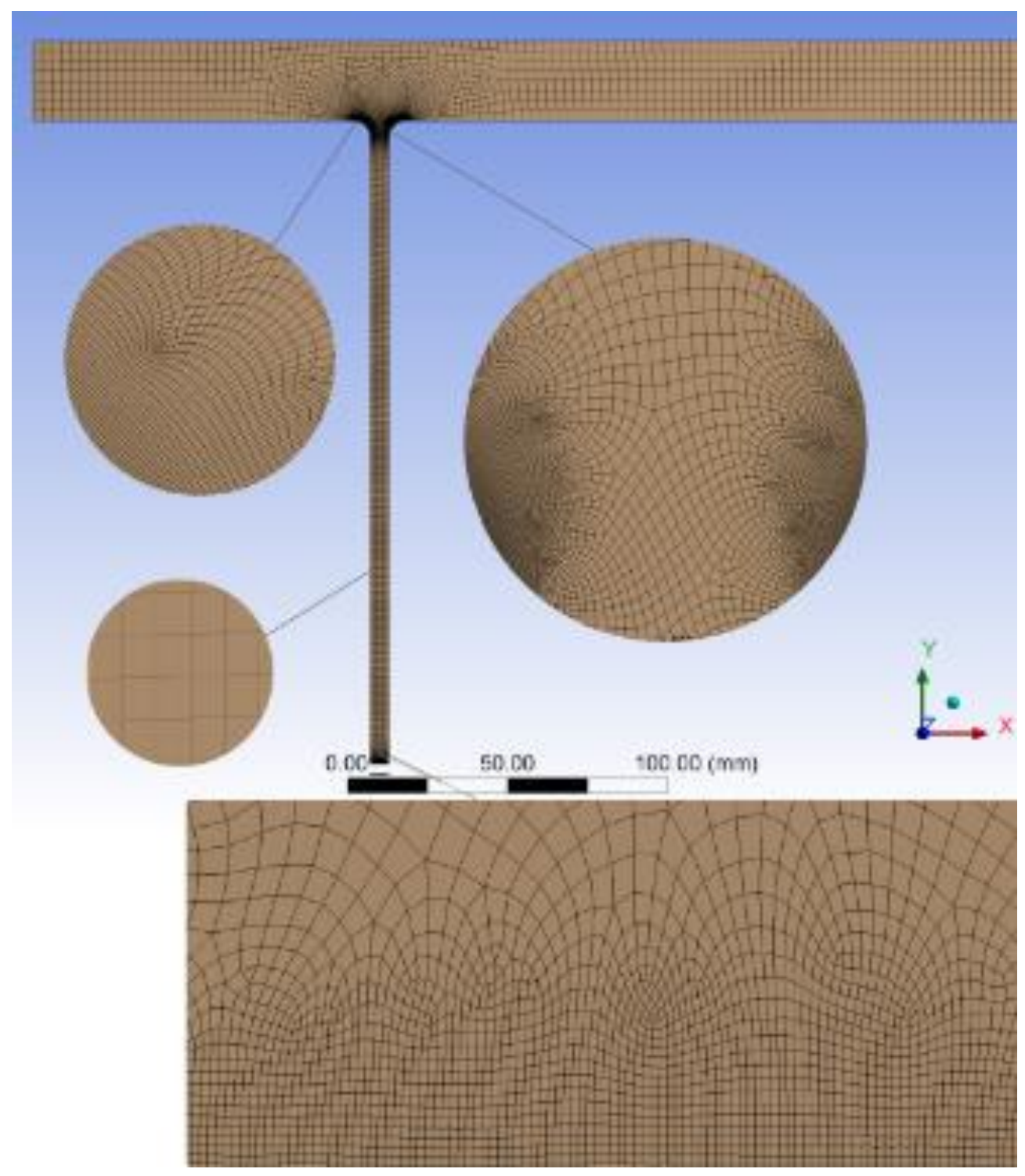

Figure 4-b

Fig. 4 The mesh for the entire piping water system of micro sprinkler network

Figures 5-a and 5-b represent water velocity contours profile once it is out of the sprinkler tube. The comparison between the two simulations indicates that any increment of the pressure is associated with higher 
velocity of water. Hence, a chaotic rapid movement will be produced. This might be useful to make the sprinkler tube of heavier material to control the rapid movement and thus enhance water distribution efficiency. As shown in the figures low operating pressure covers less area in comparison to higher pressure. The results therefore suggest that the combination of both operating conditions and using tubes as support to the micro sprinkler flexible tube can improve the performance (different efficiency indicators such as CCU and DU) of micro sprinkler irrigation networks.

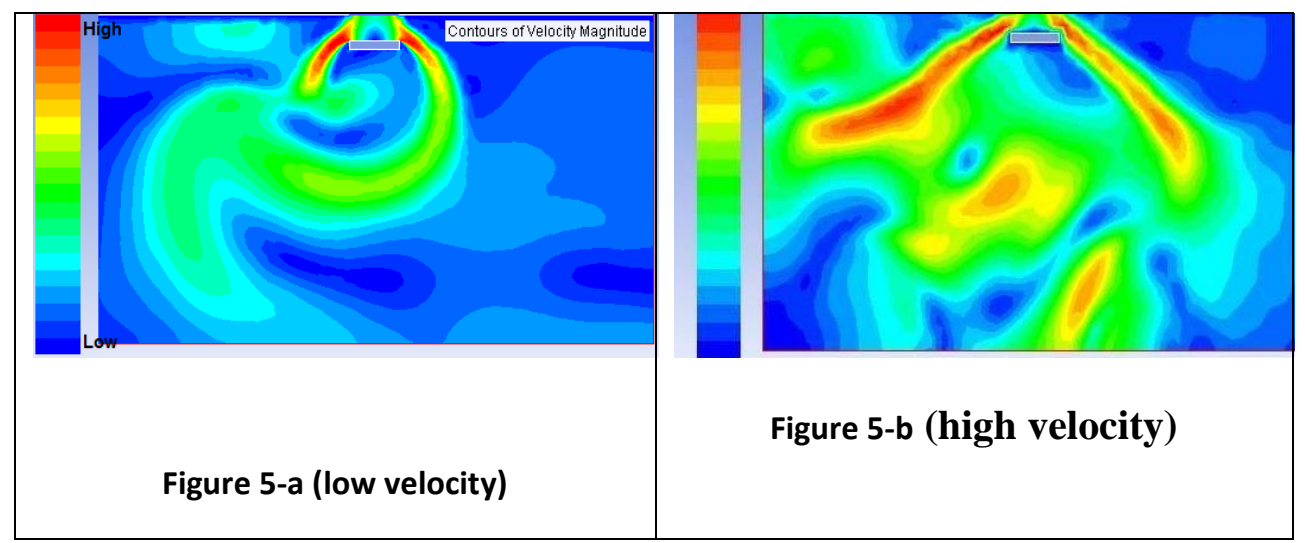

Fig. 5 Water velocity contours at high velocity (b) and low velocity (a); red color, high velocity; light green, medium velocity; blue color, low velocity

\section{Effect of operating pressure and sprinkler height on Christiansen's coefficient of uniformity}

Christiansen's coefficient of uniformity is one of the most commonly used indicator to evaluate various sprinkler irrigations systems. Table 1 details the effects of operating pressure and sprinkler height on Christiansen's coefficient of uniformity with and without support. The results revealed that increasing operating pressure up to $250 \mathrm{kPa}$ increased CCU. The maximum CCU of 91.8 was recorded with $250 \mathrm{kPa}$ at $1.5 \mathrm{~m}$ sprinkler height while the minimum CCU value of 50.3 was recorded with $180 \mathrm{kPa}$ operating pressure at $0.5 \mathrm{~m}$ sprinkler height. It is also shown that using support of both PVC and copper tubes improved water distribution efficiency and therefore high CCU values at most levels of operating 
pressure and sprinkler height. The results therefore showed better performance of micro sprinkler supported by PVC and copper tubes. The increase in CCU values could be attributed to the decrease of random motion of the tube connecting the sprinkler head to the main line. Both PVC and copper tubes eliminate alongside water pressure and make the sprinkler more stable and resultantly more water distribution efficiency.

Table 1 Effect of operating pressure and sprinkler height on Christiansen's coefficient of uniformity with and without support

\begin{tabular}{|c|c|c|c|c|}
\hline Height, m & Pressure, kPa & Without support & PVC support & Copper \\
\hline \multirow{4}{*}{1.5} & 250 & 69.3 & 81.1 & $\underline{\mathbf{9 1 . 8}}$ \\
\cline { 2 - 5 } & 220 & 74.7 & 79.2 & 80.3 \\
\cline { 2 - 5 } & 180 & 71.4 & 78.7 & 79.1 \\
\hline \multirow{4}{*}{1} & 150 & 62.5 & 62.7 & 61.7 \\
\cline { 2 - 5 } & 250 & 67.3 & 78.9 & 80.2 \\
\cline { 2 - 5 } & 220 & 70.4 & 75.2 & 77.4 \\
\cline { 2 - 5 } & 180 & 70.6 & 74.7 & 74.6 \\
\hline \multirow{4}{*}{0.5} & 250 & 60.8 & 61.7 & 60.3 \\
\cline { 2 - 5 } & 220 & 52.4 & 62.8 & 62.8 \\
\cline { 2 - 5 } & 180 & 54.4 & 64.1 & 67.5 \\
\cline { 2 - 5 } & 150 & $\underline{\mathbf{5 0 . 3}}$ & 64.4 & 65.3 \\
\hline
\end{tabular}

Effect of operating pressure and sprinkler height on distribution uniformity of micro sprinklers

Distribution uniformity is considered one of the most commonly used indicator for evaluating various sprinkler irrigation systems. Sprinkler height and operating pressure affect the performance of sprinklers in different ways (positively or can be negatively) thus choosing the optimum operating conditions can increase water distribution efficiency. Table 2 represents this relationship showing that at $250 \mathrm{kPa}$ operating pressure distribution uniformity is high in comparison to other pressure values which can be attributed to the medium size droplets that can be spread uniformly. It is also obvious that using PVC and copper tubes 
enhanced DU at the most levels of operating pressure and sprinkler heights. Lower operating pressure produced low water distribution uniformity values. Sprinkler height positively increased water distribution uniformity as a result of increasing the coverage area. The highest water distribution uniformity of $86 \%$ was recorded with $250 \mathrm{kPa}$ operating pressure and $1.5 \mathrm{~m}$ sprinkler height while the lowest distribution uniformity values were recorded at lower height and lower pressure. Therefore, same results obtained for both CCU and DU since higher pressure and higher sprinkler height enhanced the performance of sprinklers.

Table 2 Effect of operating pressure and sprinkler height on distribution uniformity of micro sprinklers with and without support

\begin{tabular}{|c|c|c|c|c|}
\hline Height, m & Pressure, kPa & Without support & PVC support & Copper \\
\hline \multirow{4}{*}{1.5} & 250 & 0.57 & 0.70 & $\mathbf{0 . 8 6}$ \\
\cline { 2 - 5 } & 220 & 0.61 & 0.68 & 0.78 \\
\cline { 2 - 5 } & 180 & 0.66 & 0.68 & 0.69 \\
\cline { 2 - 5 } & 150 & 0.47 & 0.46 & 0.43 \\
\hline \multirow{4}{*}{1} & 250 & 0.53 & 0.55 & 0.60 \\
\cline { 2 - 5 } & 220 & 0.52 & 0.54 & 0.58 \\
\cline { 2 - 5 } & 180 & 0.49 & 0.52 & 0.57 \\
\hline \multirow{4}{*}{0.5} & 150 & 0.45 & 0.44 & 0.48 \\
\cline { 2 - 5 } & 250 & 0.34 & 0.40 & 0.45 \\
\cline { 2 - 5 } & 220 & 0.33 & 0.42 & 0.50 \\
\cline { 2 - 5 } & 180 & $\mathbf{0 . 3 2}$ & 0.42 & 0.42 \\
\hline
\end{tabular}

\section{CONCLUSION}

The improvement of irrigation technique efficiency is becoming of importance for precision irrigation because it optimizes the site specific management. The present study aimed to enhance the performance of EIN DOR micro-sprinkler irrigation system using PVC and copper tubes as a support. The performance was evaluated by calculating some indicators including distribution uniformity, and Christiansen's coefficient of uniformity. The results obtained demonstrated that low operating pressure and low sprinkler height resulted in less water distribution efficiency since high CCU and DU values were observed with higher operating 
pressure and sprinkler height. The results further showed that the maximum CCU of $91.8 \%$ was recorded at $250 \mathrm{kPa}$ operating pressure and $1.5 \mathrm{~m}$ sprinkler height with copper support and thus choosing the optimum operating conditions greatly affected water distribution efficiency. Similar results were obtained for distribution uniformity since higher uniformity was recorded with $250 \mathrm{kPa}$ and $1.5 \mathrm{~m}$. Moreover, copper and PVC tubes as a support to sprinkler tube reduced the random motion of sprinklers which enhanced the performance of irrigation network. In conclusion, the results revealed that using pipes of heavier materials to support the sprinkler long tube makes micro sprinkler irrigation systems more efficient for applying water.

\section{Acknowledgment}

The authors would like to thank Eng. Abdelrhamn Elshrombably for his contribution to the CFD work.

\section{REFERENCES}

Anderson, J. D. (1995). Computational fluid dynamics: the basics with applications (McGraw-Hill international editions. Mechanical engineering series).

Armindo, R.A.; T.A. Botrel, and T.C. Garzella (2011). Flow rate sprinkler development for site specific irrigation. Irrigation Science, 29: 233240.

ASAE (2001). American Society of Agricultural Engineers. Test procedure for determining the uniformity of water distribution of center pivot and lateral move irrigation machines equipped with spray or sprinkler nozzles. ASAE Standards, ANSI/ASAE S436.

Aung, K.H. and F.S. Thomas (2003). Introduction to micro-irrigation. North Dakota State University, NDSU Extension Service. AE-1243, March 2003.

Dechmi, F.; E. Playan; J.M. Faci; M. Tejero and A. Bercero (2003). Analysis of an irrigation district in northeastern Spain. II Irrigation evaluation, simulation and scheduling. Agric. Water Manage., 61: 93-109. 
English, M.J.; M. Asce and G.S. Nuss (1982). Designing for deficit irrigation. Irrigation and drainage Division, ASCE, 108: 91-106.

Heermann, D. F; W. W. Wallender and G. M. Bos (1990). Irrigation efficiency and uniformity. (C. F. Hoffman, G. J., Howell, T. A., Solomon, K. H. (Eds.), Management of Farm Irrigation Systems. ASAE, St. Joseph, MI. 125-149.

Li, J. and M. Rao (2000). Sprinkler water distribution as affected by winter wheat canopy. Irrigation Science, 20: 29-35.

Malalalsekera, W. and H. K. Versteeg (2007). An introduction to computational fluid dynamics: the finite volume method Harlow: Pearson Prentice Hall.

Melvyn, K. (1983). Sprinkler irrigation, equipment and practice. Batsford Academic and Educational, London pp.120.

Rijsberman, F.R. (2006). Water scarcity: fact or fiction? Agric. Water Manag., 80: 5-22.

Shendage, A.S. and Gadge, S.B. (2011). Hydraulic studies of different microsprinkler. IJAEB, 4(1): 73-76.

Wei, Q.; Y. Shi; W. Dong; J. Lu and S. Huang (2006). Study on hydraulic performance of drip emitters by computational fluid dynamics. Agric. Water Manag., 84(1-2): p. 130-136.

\section{الملخص العزبيى}

تحسين أداء نظام الرى بالرش قليل التصرف بتقليل حركة الرشاشات العثوائية

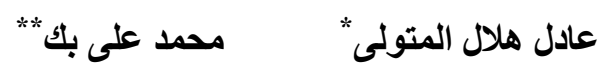

يعتبر نظام الرى بالرش احد انظمة الرى الحديثة والتى يمكن تعظيم كفاءته من خلال اختيار

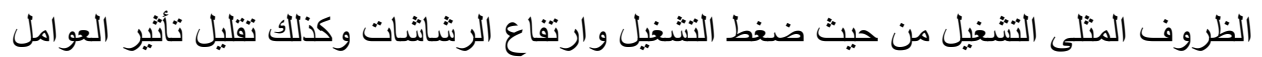
الخارجية المؤثرة على نظام الرى. ونظام الرى بالرش ذات التصرفات القيليلة ( micro

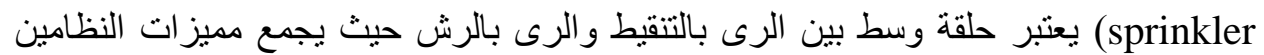

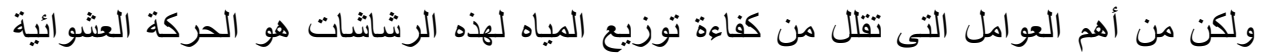

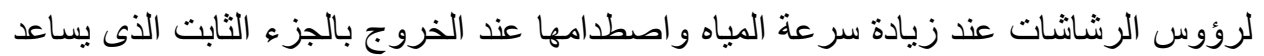

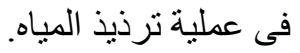

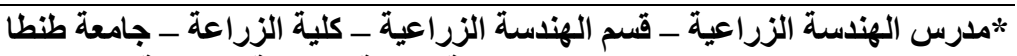

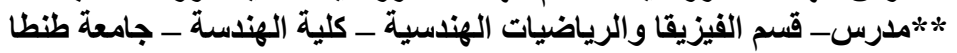


لذلك أجريت الدراسة بمزرعة خاصة لإنتاج شتلات الفاكهة والزينة بمحافظة المنوفية بهدف تحسين وتقييم أداء الرى بالرش ذات التصرفات القليلة لاختيار انسب ظروف تشغيل لنظام الرى الرى

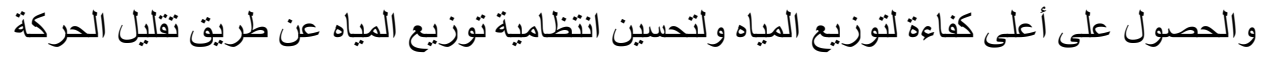

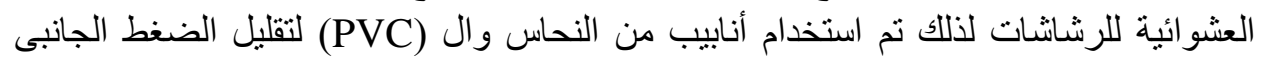

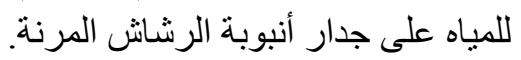

تم استخدام مستويات مختلفة من كل من ضغط التشغيل وارتفاع الرشاشات و التى كانت كالتالى:

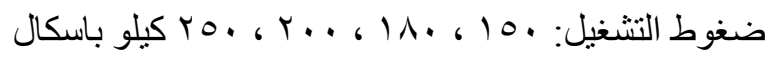

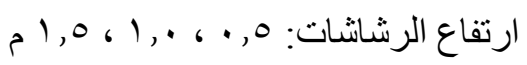

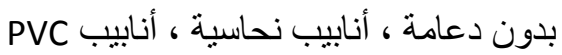

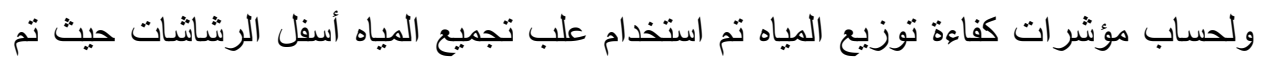

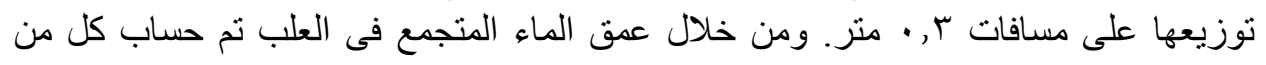

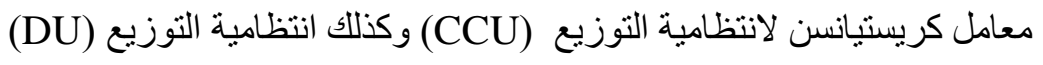

\section{وكانت أهم النتائج المتحصل عليها كالتالى:}

استخدام الأنابيب النحاسية وأنابيب ال (PVC) كدعامات للأنبوبة المرنة للرشاش الثان

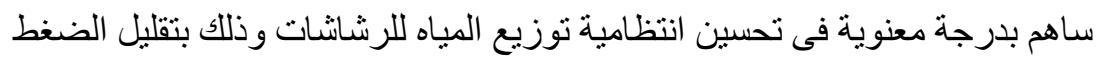

$$
\text { الجانبى على جدار الأنبوبة المرنة. }
$$

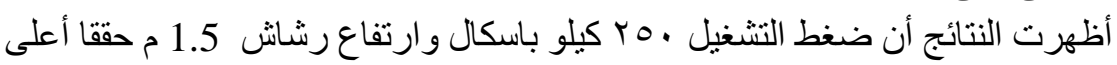

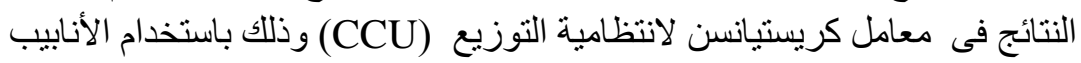

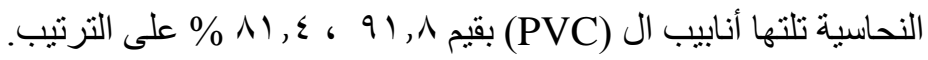

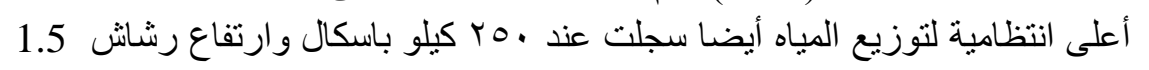

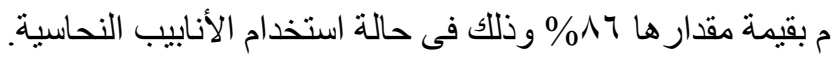

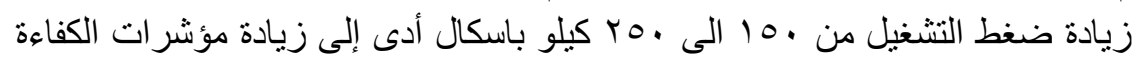

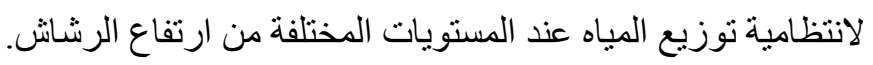

وخلصت الدر اسة إلى أن الرشناتـات قليلة التصرف ذات الأنبوبة المرنة يمكن تعظيم كفاءة توزيع

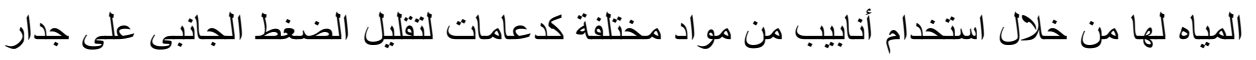

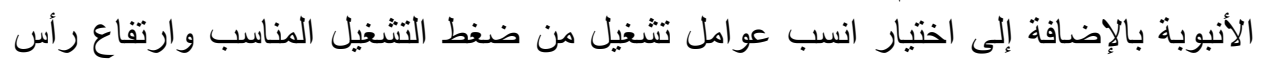
الرشاش الذى يعطى أعلى نسبة تغطية. 